\title{
DAB + Network Implementation in the Czech Republic and Impact of the Audio Coding on Subjective Perception of Sound Quality
}

\author{
Karel ZYKA \\ Czech Radio, Vinohradská 12, 12099 Prague 2, Czech Republic \\ karel.zyka@rozhlas.cz
}

Submitted October 30, 2019 / Accepted January 11, 2020

\begin{abstract}
Digital Audio Broadcasting (DAB+) is becoming a reality in the Czech Republic. The first nationwide $D A B+$ network, based on the regular broadcasting, is being completed. This paper presents the principles that were used to achieve a quick and efficient penetration of the DAB+ signal in the Czech population and the highways. Attention is focused on practical experience with the use of High-Efficiency Advanced Audio Coding (HE-AAC) emphasizing maximum efficiency of the multiplex. This is done with respect to the subjective perception of sound quality by the audience. Final audio processing and appropriate signal pre-processing are considered. The paper also focuses on how to use Forward Error Correction (FEC) coding to increase the reach of transmitters and the reasons for employing the specific transmitter network configuration, including indoor reception. The results of this complex method are demonstrated on the network rollout in particular periods, while the key assumptions were verified. The entire development process can be monitored on the maps of coverage.
\end{abstract}

\section{Keywords}

DAB, DAB+, Digital Audio Broadcasting, network, non-entropic audio coding, HE-AAC, transmitter, FEC, implementation, broadcast audio processing

\section{Introduction}

Between 2017 and 2019, the first nationwide DAB+ network [1], [2] was built in the Czech Republic. The main pioneer of radio broadcasting digitization and the implementer of this network became public service Czech Radio in cooperation with the network operator České Radiokomunikace (CRA). A series of measurements and tests were performed during the stage of experimental broadcasting [3] and this experience was used for planning and preparation of the regular broadcasting. The main attention was devoted to increasing signal coverage in the popula- tion and on highways, which was important because in-car listening represents a significant share of total radio listening. The key factors were ensuring maximum operational efficiency while keeping the highest subjectively perceived sound quality and range of services. To achieve these goals, a combination of key features of the DAB+ [2] called "Fast Penetration Strategy" was used. These features are: effective audio coding, higher protection level and high-power transmitters.

- The most efficient compression coding algorithm, HE-AAC v1/v2 [4], [5], is used in DAB + to significantly reduce the bitrate of audio programs without noticeably lowering their quality. The remaining data can be used to apply higher protection coding FEC [2]. Using HE-AAC v2 with Spectral Band Replication (SBR) and Parametric Stereo (PS) superstructures, the resulting coding efficiency is about four times higher than the previous MPEG2 [6] coding, used in the original DAB version. Even at a bitrate of $48 \mathrm{kbps}$, subjectively perceived high-quality audio transmission can be achieved in this case [3], [7].

- Highly efficient audio coding has enabled the use of higher level of protection ratio FEC $2 \mathrm{~A}$ instead of generally used FEC 3A, which is also referred to as "reference". This method generates an approximately $+4 \mathrm{~dB}$ margin [3] over the standard level FEC 3A, which increased the usable signal coverage up to twice the area compared to the FEC 3A, under certain conditions. Generally, different FEC levels provide a different trade-off between the usable audio data rate and the robustness of the transmission channel. Application of different FEC levels influences usable capacity of the channel [2].

- The backbone of the DAB+ network was created by a group of high-power transmitters (10-20 kW ERP) located at high latitudes which enabled effective and quick coverage of a significant part of the Czech population. This was complemented by low-power transmitters targeting strategic places like highways or urban agglomerations. 
This project was based on ITU-R Recommendation P.1546-2 for the frequency band $174-230 \mathrm{MHz}$ [8], on the numerical modeling of the coverage and on the Czech Radio's measurements and tests carried out before and during the construction of the network [3]. The construction of the network was divided into five stages, which were based on the chosen strategy and reflected the technological preparation and the state of international frequency coordination. Czech Radio operates its DAB+ multiplex on two channels: $12 \mathrm{C}$ and $12 \mathrm{D}$ on the basis of individual authorizations issued by the National Regulatory Authority (CTO). The radio frequencies: $227.360 \mathrm{MHz}$ (12C) in Bohemia and $229.072 \mathrm{MHz}$ (12D) in Moravia were reserved for Czech Radio. All services in this network use the FEC 2A protection ratio. The multiplex can contain 15 nationwide radio channels (audio services), each including a multimedia data channel. The audio is coded either by HE-AAC v1 with a bitrate of $80 \mathrm{kbps}$ for programs with a higher share of music or by HE-AAC v2 with a bitrate of $48 \mathrm{kbps}$ for programs with a higher share of speech. The network consists of 33 transmitters, 13 of which are high-power. All transmitters have vertical polarization.

In this paper, a detailed overview of the $\mathrm{DAB}+\mathrm{im}$ plementation in the Czech Republic is given. While DAB+ in Europe is set as new standard for radio the state of implementation varies from country to country. The terrain profile (from flat to mountainous) also plays important role.

- This paper deals with the construction of a network in the country, which represents a typical geographic model for Central and Northeastern Europe.

- Detailed information on the current situation in particular counties can be found in the official database of WorldDAB organization [9].

- The paper also demonstrates how to utilize the possibilities of modern lossy audio compression algorithms to increase the robustness of a $\mathrm{DAB}+$ network while maintaining the efficient operation and fast roll out of the network.

The paper is organized in the following manner: In Sec. 2, the particular stages of DAB+ network are described, including their visualization on the maps of coverage. Section 3 focuses on the indoor $\mathrm{DAB}+$ reception, especially in big agglomerations. In Sec. 4, the appropriate audio processing and signal pre-processing, related to used audio coding is discussed.

\section{The Stages of DAB+ Network Implementation}

\subsection{Stage 1: The Official Launch (2017)}

The first regular $\mathrm{DAB}+$ broadcasting in the Czech Republic was launched by Czech Radio on June 1, 2017 by fluent transition from the experimental mode. The experimental broadcasting, called "DAB Prague" [10], which preceded the launch, was used to test, measure and verify theoretical assumptions in real and specific conditions of the Czech Republic before the construction of the network itself [3]. The start of regular $\mathrm{DAB}+$ broadcasting and the official launch of the "CRo DAB+" multiplex was made possible by the Resolution of the Czech Government No. 730/2016 of August 24, 2016. In fact, this step represented only the formal change of the status of the transmitter Praha-město (see Fig. 1) operating in the block $12 \mathrm{C}$ with $20 \mathrm{~kW}$ ERP and its switching to the regular mode, while keeping all its existing parameters. Prague, being the country's capital was the logical beginning of this journey. This transmitter alone covered $17 \%$ of the population of the Czech Republic. The transition was carried out without any interruption and limitation of the service. The list and parameters of used transmitters are given in Tab. 1 and the appropriate map of the coverage is shown in Fig. 2.

Numerical modeling of the network coverage is based on Recommendation ITU-R P.1812-3 "A path-specific propagation prediction method" [11]. The software modeling system Radiolab version 4.3.1 from CRC Data Company was used [12]. The system runs on Windows $10 \mathrm{PC}$ platform.

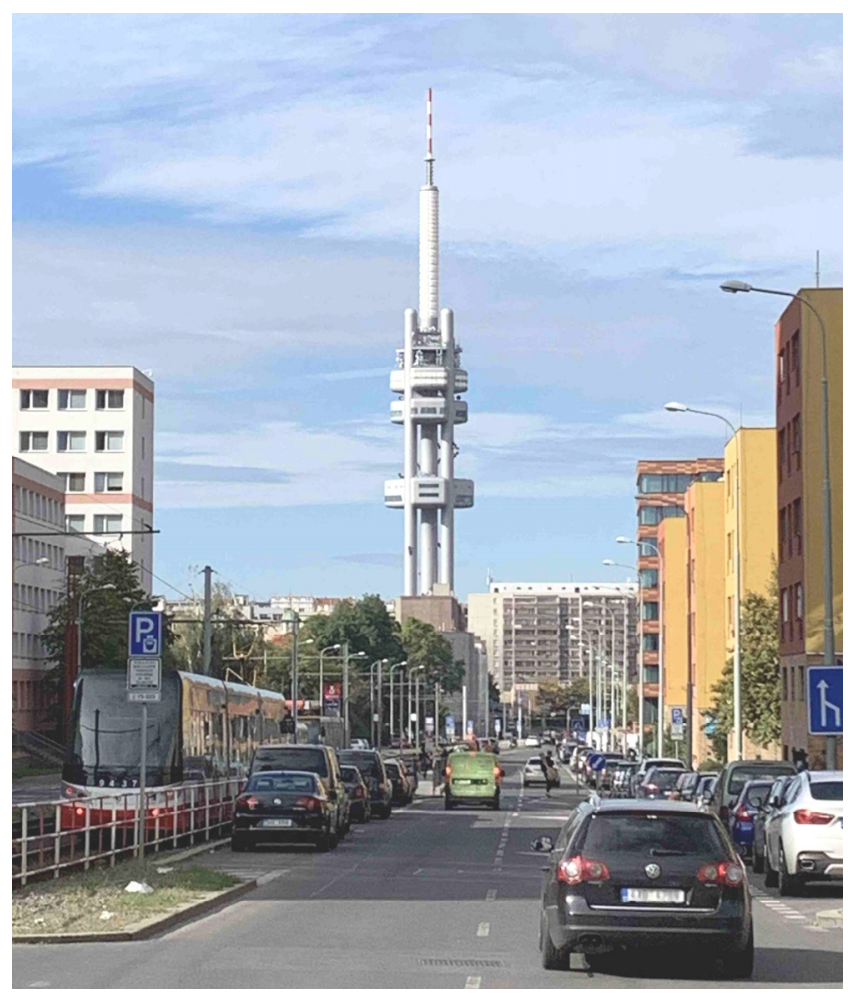

Fig. 1. The high power transmitter Praha-město (Prague-City) covering the capital of the Czech Republic and Central Bohemia is placed directly in the city.

\begin{tabular}{|l|c|c|c|c|c|c|}
\hline \multicolumn{1}{|c|}{ Transmitter site } & $\begin{array}{c}\text { RF } \\
\text { block }\end{array}$ & $\begin{array}{c}\text { ERP } \\
{[\mathrm{kW}]}\end{array}$ & pol & LON-E & LAT-N & $\begin{array}{c}\text { ant. } \\
{[\mathrm{m}]}\end{array}$ \\
\hline Praha - město & $12 \mathrm{C}$ & 20.0 & $\mathrm{~V}$ & $14^{\circ} 27^{\prime} 04^{\prime \prime}$ & $50^{\circ} 04^{\prime} 52^{\prime \prime}$ & 185 \\
\hline
\end{tabular}

Tab. 1. The list and parameters of transmitters in the stage 1 . 


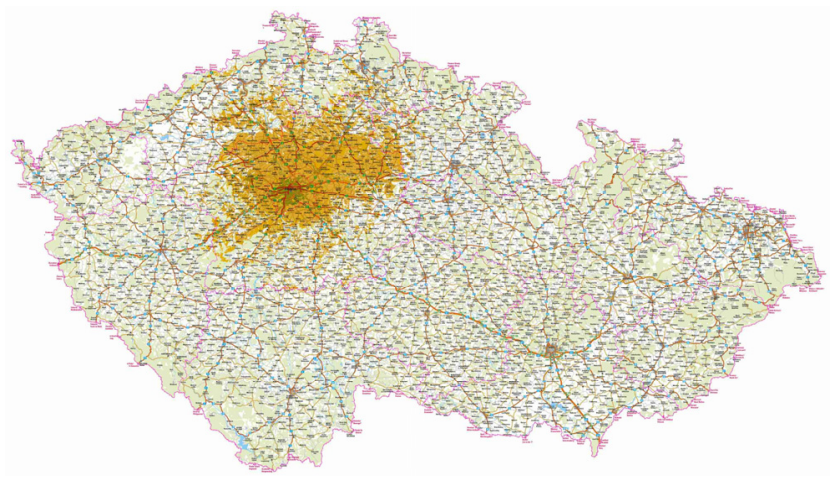

Fig. 2. The numerical modeling of the network coverage according to ITU for $58 \mathrm{~dB} \mu \mathrm{V} / \mathrm{m}$ and FEC $2 \mathrm{~A}$ in the stage 1 .

\subsection{Stage 2: Building the Basic Network (2017)}

The target of the second stage was to cover the largest urban agglomerations of the Czech Republic - Prague, Brno, Ostrava and Pilsen. After the completion of construction, the following three transmitters were launched on November 30, 2017: Brno - Hády in the block 12D with $5 \mathrm{~kW}$ ERP, Ostrava - Hoštálkovice in the block 12D with $10 \mathrm{~kW}$ ERP and Plzeň (Pilsen) - Radeč in the block 12C with $10 \mathrm{~kW}$ ERP. This basic network was completed on October 24, 2017 with the transmitter Beroun - Děd in the block $12 \mathrm{C}$ with $300 \mathrm{~W}$ ERP, which ensured homogeneous coverage of the D5 highway in the area between Prague and Pilsen transmitters. It was also a part of the "DAB Prague" experiment and it became the first transmitter on which the optimal setting of parameters for building the

\begin{tabular}{|l|r|r|r|l|l|r|}
\hline \multicolumn{1}{|c|}{ Transmitter site } & $\begin{array}{c}\text { RF } \\
\text { block }\end{array}$ & $\begin{array}{c}\text { ERP } \\
{[\mathrm{kW}]}\end{array}$ & pol & LON-E & LAT-N & $\begin{array}{c}\text { ant. } \\
{[\mathrm{m}]}\end{array}$ \\
\hline Praha - město & $12 \mathrm{C}$ & 20.0 & $\mathrm{~V}$ & $14^{\circ} 27^{\prime} 04^{\prime \prime}$ & $50^{\circ} 04^{\prime} 52^{\prime \prime}$ & 185 \\
\hline Brno - Hády & $12 \mathrm{D}$ & 5.0 & $\mathrm{~V}$ & $16^{\circ} 40^{\prime} 29^{\prime \prime}$ & $49^{\circ} 13^{\prime} 21^{\prime \prime}$ & 54 \\
\hline Ostrava - Hošt’álkovice & $12 \mathrm{D}$ & 10.0 & $\mathrm{~V}$ & $18^{\circ} 12^{\prime} 45^{\prime \prime}$ & $49^{\circ} 51^{\prime} 41^{\prime \prime}$ & 101 \\
\hline Plzeň - Radeč & $12 \mathrm{C}$ & 10.0 & $\mathrm{~V}$ & $13^{\circ} 40^{\prime} 13^{\prime \prime}$ & $49^{\circ} 49^{\prime} 22^{\prime \prime}$ & 58 \\
\hline Beroun - Děd & $12 \mathrm{C}$ & 0.3 & $\mathrm{~V}$ & $14^{\circ} 03^{\prime} 22^{\prime \prime}$ & $49^{\circ} 58^{\prime} 15^{\prime \prime}$ & 33 \\
\hline
\end{tabular}

Tab. 2. The list and parameters of transmitters in the stage 2 (the new ones are marked in bold).

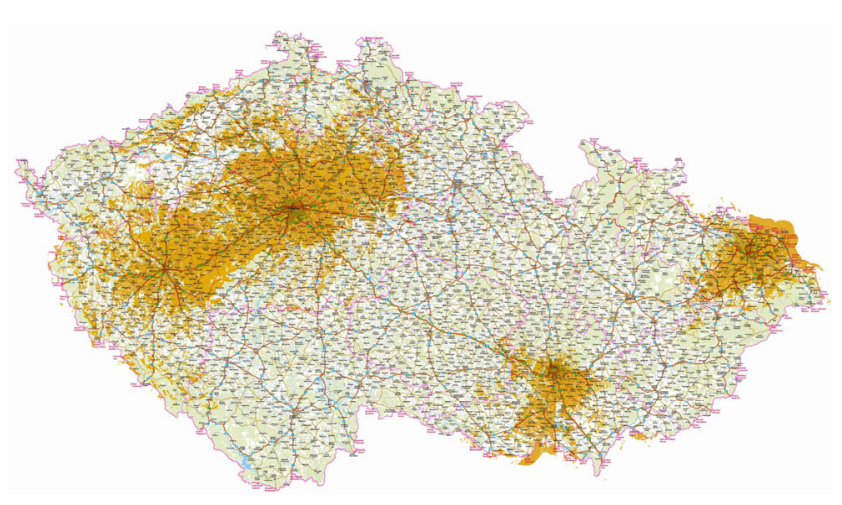

Fig. 3. The numerical modeling of the network coverage according to ITU for $58 \mathrm{~dB} \mu \mathrm{V} / \mathrm{m}$ and FEC $2 \mathrm{~A}$ in the stage 2 .
SFN network was tested. When the second stage was finished, the network coverage reached $40.8 \%$ of the population of the Czech Republic. The first continuous section of the highway was also covered. You can see the list and parameters of used transmitters in Tab. 2 and the map of the coverage in Fig. 3.

\subsection{Stage 3: Highways Coverage (2018)}

About a year after the launch of the second stage of the DAB + network, Czech Radio initiated the third stage on December 28, 2018. It was focused primarily on the coverage of highways, but also on other densely populated agglomerations, this time in Northern and Eastern Bohemia. Two high power transmitters were added to the five previously launched transmitters: Ústí nad Labem Buková Hora in the block $12 \mathrm{C}$ with $10 \mathrm{~kW}$ ERP and Trutnov - Černá Hora in the block $12 \mathrm{C}$ with 10 kW ERP. The last, frontier territory of the first highway D5, was covered by the transmitter Tachov - Rozsocha in the block $12 \mathrm{C}$ with $1 \mathrm{~kW}$ ERP. The main goal, however, was to ensure a high-quality $\mathrm{DAB}+$ signal on the key transport line, the D1 highway, starting with the section between Prague and Brno. This was made by so-called "ribbon coverage" with the central transmitter Jihlava - Strážník in the block 12D with $5 \mathrm{~kW}$ ERP and three low-power transmitters, each with directional antenna diagrams on both sides, concentrating the radiation pattern on the highway itself. Towards Prague it is Kácov - Zliv, Měchnov - Vrchy, Čtyřkoly - Dubsko, all in the block 12C with $300 \mathrm{~W}$ ERP. Towards Brno it is Velké Meziříčí Fajtův vrch, Křoví - rozcestí and Rosice - obora, all in the block 12D, again with $300 \mathrm{~W}$ ERP. Ten new transmitters increased the coverage of this network up to $61 \%$ of the population of the Czech Republic and ensured a high quality DAB + signal on most of the Czech highways (D1, D5, D8, D10 and D11). The list and parameters of used transmitters are provided in Tab. 3 and the appropriate map of the coverage is displayed in Fig. 4.

\begin{tabular}{|l|r|r|r|l|l|r|}
\hline \multicolumn{1}{|c|}{ Transmitter site } & $\begin{array}{r}\text { RF } \\
\text { block }\end{array}$ & $\begin{array}{c}\text { ERP } \\
{[\mathrm{kW}]}\end{array}$ & pol & LON-E & LAT-N & $\begin{array}{r}\text { ant. } \\
{[\mathrm{m}]}\end{array}$ \\
\hline Praha - město & $12 C$ & 20.0 & $V$ & $14^{\circ} 27^{\prime} 04^{\prime \prime}$ & $50^{\circ} 04^{\prime} 52^{\prime \prime}$ & 185 \\
\hline Brno - Hády & $12 \mathrm{D}$ & 5.0 & $V$ & $16^{\circ} 40^{\prime} 29^{\prime \prime}$ & $49^{\circ} 13^{\prime} 21^{\prime \prime}$ & 54 \\
\hline Ostrava - Hošt'álkovice & $12 \mathrm{D}$ & 10.0 & $V$ & $18^{\circ} 12^{\prime} 45^{\prime \prime}$ & $49^{\circ} 51^{\prime} 41^{\prime \prime}$ & 101 \\
\hline Plzen̆ - Radeč & $12 \mathrm{C}$ & 10.0 & $V$ & $13^{\circ} 40^{\prime} 13^{\prime \prime}$ & $49^{\circ} 49^{\prime} 22^{\prime \prime}$ & 58 \\
\hline Beroun - Děd & $12 \mathrm{C}$ & 0.3 & $V$ & $14^{\circ} 03^{\prime} 22^{\prime \prime}$ & $49^{\circ} 58^{\prime} 15^{\prime \prime}$ & 33 \\
\hline Ústí n. L. - Buková hora & $12 \mathrm{C}$ & 10.0 & $\mathrm{~V}$ & $14^{\circ} 13^{\prime} 44^{\prime \prime}$ & $50^{\circ} 40^{\prime} 18^{\prime \prime}$ & 185 \\
\hline Trutnov - Černá hora & $12 \mathrm{C}$ & 10.0 & $\mathrm{~V}$ & $15^{\circ} 44^{\prime} 30^{\prime \prime}$ & $50^{\circ} 39^{\prime} 09^{\prime \prime}$ & 35 \\
\hline Čtyřkoly - Dubsko & $12 \mathrm{C}$ & 0.2 & $\mathrm{~V}$ & $14^{\circ} 44^{\prime} 17^{\prime \prime}$ & $49^{\circ} 52^{\prime} 16^{\prime \prime}$ & 34 \\
\hline Měchnov - Vrchy & $12 \mathrm{C}$ & 0.2 & $\mathrm{~V}$ & $14^{\circ} 53^{\prime} 31^{\prime \prime}$ & $49^{\circ} 47^{\prime} 47^{\prime \prime}$ & 58 \\
\hline Kácov - Zliv & $12 \mathrm{C}$ & 0.2 & $\mathrm{~V}$ & $15^{\circ} 01^{\prime} 55^{\prime \prime}$ & $49^{\circ} 46^{\prime} 00^{\prime \prime}$ & 34 \\
\hline Jihlava - Strážník & $12 \mathrm{D}$ & 5.0 & $\mathrm{~V}$ & $15^{\circ} 27^{\prime} 14^{\prime \prime}$ & $49^{\circ} 28^{\prime} 10^{\prime \prime}$ & 42 \\
\hline Velké Meziříćí-Fajt. vrch & $12 \mathrm{D}$ & 0.2 & $\mathrm{~V}$ & $16^{\circ} 01^{\prime} 13^{\prime \prime}$ & $49^{\circ} 21^{\prime} 34^{\prime \prime}$ & 34 \\
\hline Křoví - rozcestí & $12 \mathrm{D}$ & 0.2 & $\mathrm{~V}$ & $16^{\circ} 15^{\prime} 38^{\prime \prime}$ & $49^{\circ} 18^{\prime} 59^{\prime \prime}$ & 24 \\
\hline Rosice - obora & $12 \mathrm{D}$ & 0.2 & $\mathrm{~V}$ & $16^{\circ} 22^{\prime} 43^{\prime \prime}$ & $49^{\circ} 10^{\prime} 37^{\prime \prime}$ & 34 \\
\hline Tachov - Rozsocha & $12 \mathrm{C}$ & 1.0 & $\mathrm{~V}$ & $12^{\circ} 35^{\prime} 15^{\prime \prime}$ & $49^{\circ} 45^{\prime} 50^{\prime \prime}$ & 48 \\
\hline
\end{tabular}

Tab. 3. The list and parameters of transmitters in the stage 3 (the new ones are marked in bold). 


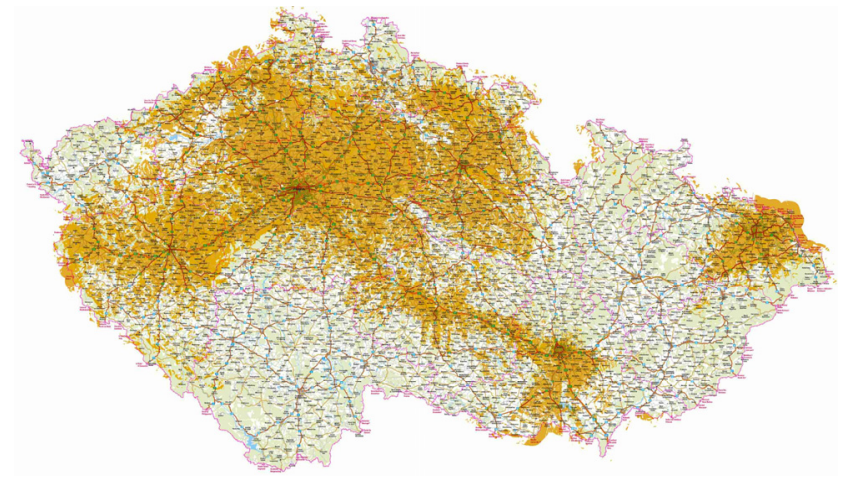

Fig. 4. The numerical modeling of the network coverage according to ITU for $58 \mathrm{~dB} \mu \mathrm{V} / \mathrm{m}$ and FEC $2 \mathrm{~A}$ in the stage 3 .

\subsection{Stage 4: Reaching Nationwide Coverage (2019)}

In November 2019, the fourth stage of the network rollout was initiated. Its primary objective was to complete the coverage of the remaining section of the D1 highway from Brno to Ostrava and the coverage of the remaining dense urban agglomerations, this time in South Bohemia and Moravia. Four high power transmitters were added to the network: České Budějovice - Klet' in the block $12 \mathrm{C}$ with $20 \mathrm{~kW}$ ERP, Jáchymov - Klínovec in the block 12C with $10 \mathrm{~kW}$ ERP, Brno - Kojál (see Fig. 5) and Zlín Tlustá hora, both in the block 12D with $10 \mathrm{~kW}$ ERP. These transmitters cover South Bohemia, Zlín and Karlovy Vary regions, as well as Central Moravia. The Olomouc region covers the Olomouc - Radíkov transmitter in the block 12D with $2 \mathrm{~kW}$ ERP, which together with the transmitter Nový

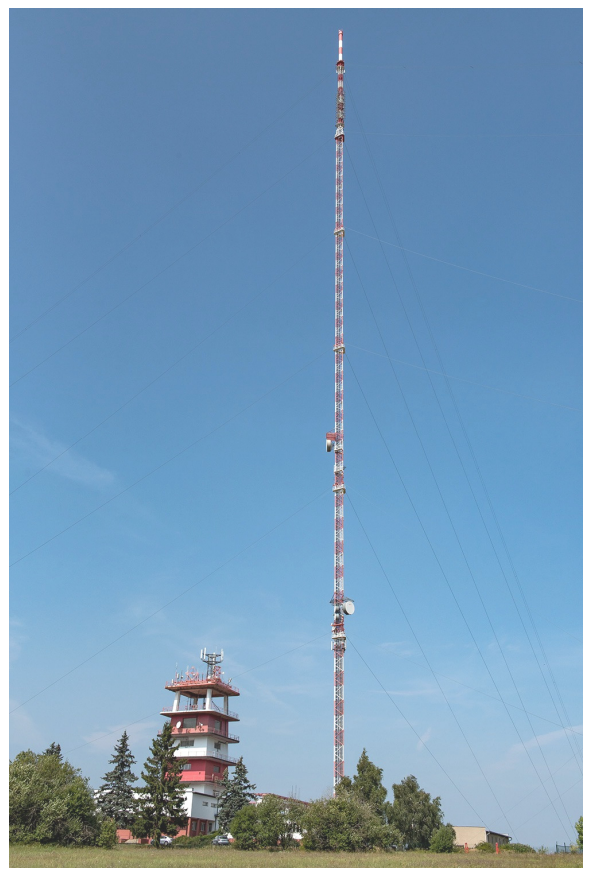

Fig. 5. The high power transmitter Brno - Kojál with antennas $305 \mathrm{~m}$ above the earth is effectively covering South and Central Moravia.

\begin{tabular}{|c|c|c|c|c|c|c|}
\hline Transmitter site & $\begin{array}{c}\mathrm{RF} \\
\text { block }\end{array}$ & $\begin{array}{c}\text { ERP } \\
{[\mathrm{kW}]}\end{array}$ & pol & LON-E & LAT-N & $\begin{array}{l}\text { ant. } \\
\text { [m] }\end{array}$ \\
\hline Praha-mèsto & $12 \mathrm{C}$ & 20.0 & $\mathrm{~V}$ & $14^{\circ} 27^{\prime} 04^{\prime \prime}$ & $50^{\circ} 04^{\prime} 52^{\prime \prime}$ & 185 \\
\hline Brno - Hády & $12 D$ & 5.0 & V & $16^{\circ} 40^{\prime} 29^{\prime \prime}$ & $49^{\circ} 13^{\prime} 21^{\prime \prime}$ & 54 \\
\hline Ostrava-Hoštálkovice & $12 D$ & 10.0 & $\bar{V}$ & $18^{\circ} 12^{\prime} 45^{\prime \prime}$ & $49^{\circ} 51^{\prime} 41^{\prime \prime}$ & 101 \\
\hline Plzeñ-Radeč & $12 \mathrm{C}$ & 10.0 & $\bar{V}$ & $13^{\circ} 40^{\prime} 13^{\prime \prime}$ & $49^{\circ} 49^{\prime} 22^{\prime \prime}$ & 58 \\
\hline Beroun-Déd & $12 \mathrm{C}$ & 0.3 & V & $14^{\circ} 03^{\prime} 22^{\prime \prime}$ & $49^{\circ} 58^{\prime} 15^{\prime \prime}$ & 33 \\
\hline Ústí n. L. - Buková hora & $12 \mathrm{C}$ & 10.0 & $\bar{V}$ & $14^{\circ} 13^{\prime} 44^{\prime \prime}$ & $50^{\circ} 40^{\prime} 18^{\prime \prime}$ & 185 \\
\hline Trutnov- Černá hora & $12 \mathrm{C}$ & 10.0 & $\bar{V}$ & $15^{\circ} 44^{\prime} 30^{\prime \prime}$ & $50^{\circ} 39^{\prime} 09^{\prime \prime}$ & 35 \\
\hline Čtyřkoly - Dubsko & $12 C$ & 0.2 & $\bar{V}$ & $14^{\circ} 44^{\prime} 17^{\prime \prime}$ & $49^{\circ} 52^{\prime} 16^{\prime \prime}$ & 34 \\
\hline Měchnov-Vrchy & $12 C$ & 0.2 & V & $14^{\circ} 53^{\prime} 31^{\prime \prime}$ & $49^{\circ} 47^{\prime} 47^{\prime \prime}$ & 58 \\
\hline Kácov-Zliv & $12 \mathrm{C}$ & 0.2 & $\bar{V}$ & $15^{\circ} 01^{\prime} 55^{\prime \prime}$ & $49^{\circ} 46^{\prime} 00^{\prime \prime}$ & 34 \\
\hline Jihlava-Strážník & $12 D$ & 5.0 & $\bar{V}$ & $15^{\circ} 27^{\prime} 14^{\prime \prime}$ & $49^{\circ} 28^{\prime} 10^{\prime \prime}$ & 42 \\
\hline Velké Meziřiči - Fajt. vrch & $12 D$ & 0.2 & $\bar{V}$ & $16^{\circ} 01^{\prime} 13^{\prime \prime}$ & $49^{\circ} 21^{\prime} 34^{\prime \prime}$ & 34 \\
\hline Křví - rozcestí & $12 D$ & 0.2 & $\bar{V}$ & $16^{\circ} 15^{\prime} 38^{\prime \prime}$ & $49^{\circ} 18^{\prime} 59^{\prime \prime}$ & 24 \\
\hline Rosice-obora & $12 D$ & 0.2 & $\bar{V}$ & $16^{\circ} 22^{\prime} 43^{\prime \prime}$ & $49^{\circ} 10^{\prime} 37^{\prime \prime}$ & 34 \\
\hline Tachov-Rozsocha & $12 \mathrm{C}$ & 1.0 & $\bar{V}$ & $12^{\circ} 35^{\prime} 15^{\prime \prime}$ & $49^{\circ} 45^{\prime} 50^{\prime \prime}$ & 48 \\
\hline České Budějovice - Klet' & $12 \mathrm{C}$ & 20.0 & $\bar{V}$ & $14^{\circ} 16^{\prime} 53^{\prime \prime}$ & $48^{\circ} 52^{\prime} 03^{\prime \prime}$ & 115 \\
\hline Jáchymov - Klínovec & $12 \mathrm{C}$ & 10.0 & $\mathrm{~V}$ & \begin{tabular}{|l|}
$2^{\circ} 58^{\prime} 04^{\prime \prime}$ \\
\end{tabular} & $50^{\circ} 23^{\prime} 49^{\prime \prime}$ & 65 \\
\hline Brno - Kojál & $12 \mathrm{D}$ & 10.0 & $\mathrm{~V}$ & $16^{\circ} 48^{\prime} 59^{\prime \prime}$ & $49^{\circ} 22^{\prime} 11^{\prime \prime}$ & 305 \\
\hline Zlín - Tlustá hora & $12 \mathrm{D}$ & 10.0 & $\mathrm{~V}$ & $17^{\circ} 38^{\prime} 47^{\prime \prime}$ & $49^{\circ} 12^{\prime} 30^{\prime \prime}$ & 65 \\
\hline Klatovy - Doubrava & $12 \mathrm{C}$ & 5.0 & $\mathrm{~V}$ & $13^{\circ} 12^{\prime} 15^{\prime \prime}$ & $49^{\circ} 25^{\prime} 56^{\prime \prime}$ & 35 \\
\hline Olomouc - Radíkov & $12 \mathrm{D}$ & 2.0 & $\overline{\mathrm{V}}$ & $17^{\circ} 22^{\prime} 05^{\prime \prime}$ & $49^{\circ} 38^{\prime} 32^{\prime \prime}$ & 67 \\
\hline Plzeň - Sylván & $12 \mathrm{C}$ & 1.0 & $\mathrm{~V}$ & $13^{\circ} 20^{\prime} 58^{\prime \prime}$ & $49^{\circ} 46^{\prime} 14^{\prime \prime}$ & 50 \\
\hline Nový Jičín - Veselý kopec & $12 \mathrm{D}$ & 1.0 & $\mathrm{~V}$ & $17^{\circ} 48^{\prime} 19^{\prime \prime}$ & $49^{\circ} 38^{\prime} 40^{\prime \prime}$ & 69 \\
\hline Tasov - Za šibenicí & $12 \mathrm{D}$ & 0.3 & $\mathrm{~V}$ & $16^{\circ} 06^{\prime} 52^{\prime \prime}$ & $49^{\circ} 16^{\prime} 51^{\prime \prime}$ & 21 \\
\hline
\end{tabular}

Tab. 4. The list and parameters of transmitters in the stage 4 (the new ones are marked in bold).

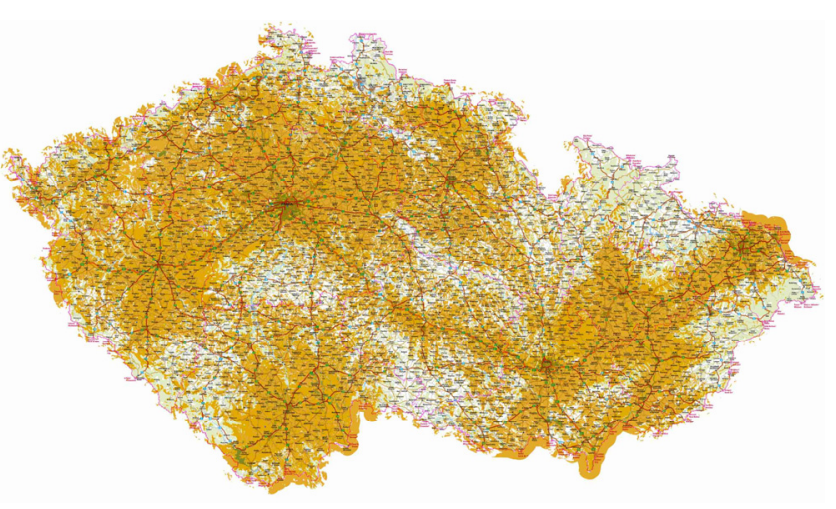

Fig. 6. The numerical modeling of the network coverage according to ITU for $58 \mathrm{~dB} \mu \mathrm{V} / \mathrm{m}$ and FEC $2 \mathrm{~A}$ in the stage 4 .

Jičín - Veselý kopec in the block 12D with $1 \mathrm{~kW}$ ERP and especially with the above-mentioned transmitter Kojál, will ensure sufficient coverage of the remaining part of the D1 highway between Brno and Ostrava.

After the evaluation of the previous stages, based on signal measurements and real receiving conditions, the transmitter Pilsen - Sylván was added in the block 12C with $1 \mathrm{~kW}$ ERP, which significantly improved coverage directly in this city. The indoor coverage in Pilsen was not sufficient due to the longer distance from the main regional transmitter Plzeň - Radeč. For the same reasons, low-power transmitter Tasov - Za šibenicí in the block 12D with $300 \mathrm{~W}$ ERP was also added. Its task is to increase the homogeneity of the ribbon coverage field of the D1 high- 
way. The transmitter Klatovy - Doubrava in the block 12C with $5 \mathrm{~kW}$ ERP increases the homogeneity of electromagnetic field in the West of the Pilsen region. Nine new transmitters increase the coverage of this network up to $80 \%$ of the Czech population. The list and parameters of used transmitters can be seen in Tab. 4 and the map of the coverage in Fig. 6.

\subsection{Stage 5: Increasing Network Robustness}

The fifth and final stage of the DAB + implementation aims to increase the network's robustness and to cover the remaining problematic or not yet covered areas. They were chosen based on not only the numerical modeling of the network coverage (according to ITU) [8], but also on the measurement of electromagnetic field intensity, Bit Error Rate (BER) and Modulation Error Ratio (MER) values at specific locations in field. The correlation between signal strength, MER, BER and reception quality depends not only on MER values, which practically indicate the signal-to-noise ratio (SNR) at the receiver demodulator input, but also on the nature of this noise. The noise pattern received in SFN networks often differs from the Gaussian distribution. This makes it generally difficult to analyze the relationship between MER and BER. Subjectively undisturbed sound quality of the reception depends mainly on BER values. Based on our measurements and listening tests it can be said that BER level must be less than $2.5 \mathrm{E}-5$ for quality reception. This corresponds to MER level higher than $26.5 \mathrm{~dB}$ and to signal strength of approximately $50 \mathrm{~dB} \mu \mathrm{V} / \mathrm{m}$ for FEC $2 \mathrm{~A}$ protection level. Control listening was performed for 5 minutes at each measuring point. Field measurement vehicles were equipped with an analyzer R\&S ETL, car DAB+ receiver Blaupunkt Stockholm 230 DAB, GPS receiver SveeSix Trimble and a logarithmic-periodic antenna R\&S HL223.

The core is formed by four high power transmitters. The transmitter Votice - Mezivrata in the block 12C with $10 \mathrm{~kW}$ ERP covers South of Central Bohemia. The transmitter Jihlava - Javořice in the block $12 \mathrm{D}$ with $10 \mathrm{~kW}$ ERP covers South of Vysočina region. The third one, Pardubice - Krásné in the block 12C with $10 \mathrm{~kW}$ ERP, covers South of Pardubice region and the fourth one, Jeseník - Praděd in the block 12D with $10 \mathrm{~kW}$ ERP covers the Jeseníky area. To improve the indoor reception and to increase the homogeneity of the electromagnetic field, it was necessary to add local low-power transmitters in several cities. In Liberec, the transmitter Liberec - Proseč in the block 12C with $1 \mathrm{~kW}$ ERP was added. In Znojmo, the transmitter Znojmo Kuchařovice in the block 12D with $300 \mathrm{~W}$ ERP was added and in Třinec, the transmitter Třinec - Javorový in the block $12 \mathrm{D}$ with $1 \mathrm{~kW}$ ERP was added. Within this stage, the areas with a lower population density but with significant tourism were also covered. The transmitter Sušice Svatobor in the block $12 \mathrm{C}$ with $1 \mathrm{~kW}$ ERP covers the area of Šumava and the transmitter Valašské Meziříčí - Radhošt' in the block $12 \mathrm{D}$ with $1 \mathrm{~kW}$ ERP covers the area of
Beskydy. The network coverage of the DAB + by this fifth stage reaches $95 \%$ of the population of the Czech Republic. The list and parameters of transmitters is given in Tab. 5 and the appropriate map of the coverage is illustrated in Fig. 7.

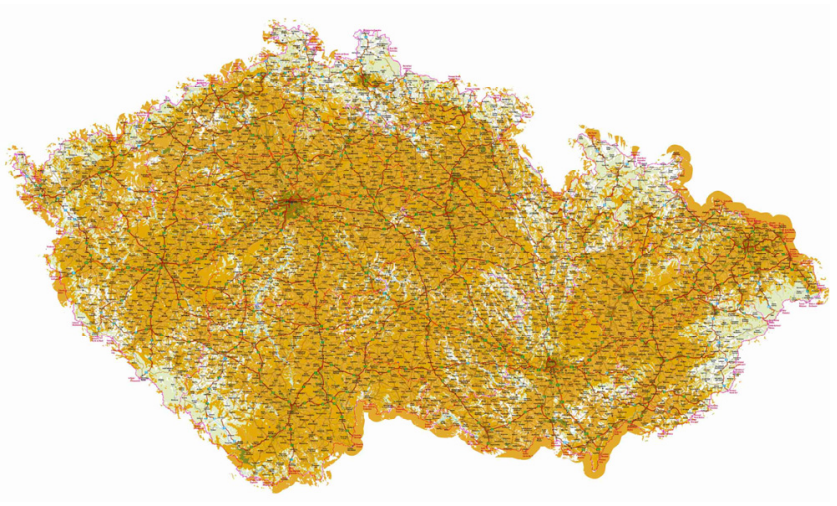

Fig. 7. The numerical modeling of the network coverage according to ITU for $58 \mathrm{~dB} \mu \mathrm{V} / \mathrm{m}$ and FEC $2 \mathrm{~A}$ in the stage 5 .

\begin{tabular}{|c|c|c|c|c|c|c|}
\hline Transmitter site & $\begin{array}{c}\text { RF } \\
\text { block }\end{array}$ & $\begin{array}{l}\text { ERP } \\
{[\mathrm{kW}]}\end{array}$ & pol & LON-E & LAT-N & $\begin{array}{l}\text { ant. } \\
{[\mathrm{m}]}\end{array}$ \\
\hline Praha - město & $12 C$ & 20.0 & V & $14^{\circ} 27^{\prime} 04^{\prime \prime}$ & $50^{\circ} 04^{\prime} 52^{\prime \prime}$ & 185 \\
\hline Brno - Hády & $12 D$ & 5.0 & $V$ & $16^{\circ} 40^{\prime} 29^{\prime \prime}$ & $49^{\circ} 13^{\prime} 21^{\prime \prime}$ & 54 \\
\hline Ostrava-Hoštálkovice & $12 D$ & 10.0 & $V$ & $18^{\circ} 12^{\prime} 45^{\prime \prime}$ & $49^{\circ} 51^{\prime} 41^{\prime \prime}$ & 101 \\
\hline Plzeñ - Radeč & $12 C$ & 10.0 & $V$ & $13^{\circ} 40^{\prime} 13^{\prime \prime}$ & $49^{\circ} 49^{\prime} 22^{\prime \prime}$ & 58 \\
\hline Beroun - Děd & $12 C$ & 0.3 & $V$ & $14^{\circ} 03^{\prime} 22^{\prime \prime}$ & $49^{\circ} 58^{\prime} 15^{\prime \prime}$ & 33 \\
\hline Ústí n. L. - Buková hora & $12 C$ & 10.0 & $V$ & $14^{\circ} 13^{\prime} 44^{\prime \prime}$ & $50^{\circ} 40^{\prime} 18^{\prime \prime}$ & 185 \\
\hline Trutnov-Černá hora & $12 C$ & 10.0 & $V$ & $15^{\circ} 44^{\prime} 30^{\prime \prime}$ & $50^{\circ} 39^{\prime} 09^{\prime \prime}$ & 35 \\
\hline Čtyřkoly - Dubsko & $12 C$ & 0.2 & $V$ & $14^{\circ} 44^{\prime} 17^{\prime \prime}$ & $49^{\circ} 52^{\prime} 16^{\prime \prime}$ & 34 \\
\hline Měchnov - Vrchy & $12 C$ & 0.2 & $V$ & $14^{\circ} 53^{\prime} 31^{\prime \prime}$ & $49^{\circ} 47^{\prime} 47^{\prime \prime}$ & 58 \\
\hline Kácov-Zliv & $12 C$ & 0.2 & $V$ & $15^{\circ} 01^{\prime} 55^{\prime \prime}$ & $49^{\circ} 46^{\prime} 00^{\prime \prime}$ & 34 \\
\hline Jihlava - Strážník & $12 D$ & 5.0 & $V$ & $15^{\circ} 27^{\prime} 14^{\prime \prime}$ & $49^{\circ} 28^{\prime} 10^{\prime \prime}$ & 42 \\
\hline Velké Meziřiči - Fajt. vrch & $12 D$ & 0.2 & $V$ & $16^{\circ} 01^{\prime} 13^{\prime \prime}$ & $49^{\circ} 21^{\prime} 34^{\prime \prime}$ & 34 \\
\hline Křroví - rozcestí & $12 D$ & 0.2 & $V$ & $16^{\circ} 15^{\prime} 38^{\prime \prime}$ & $49^{\circ} 18^{\prime} 59^{\prime \prime}$ & 24 \\
\hline Rosice - obora & $12 D$ & 0.2 & $V$ & $16^{\circ} 22^{\prime} 43^{\prime \prime}$ & $49^{\circ} 10^{\prime} 37^{\prime \prime}$ & 34 \\
\hline Tachov-Rozsocha & $12 C$ & 1.0 & $V$ & $12^{\circ} 35^{\prime} 15^{\prime \prime}$ & $49^{\circ} 45^{\prime} 50^{\prime \prime}$ & 48 \\
\hline České Budějovice - Klet' & $12 C$ & 20.0 & $V$ & $14^{\circ} 16^{\prime} 53^{\prime \prime}$ & $48^{\circ} 52^{\prime} 03^{\prime \prime}$ & 115 \\
\hline Jáchymov - Klínovec & $12 C$ & 10.0 & $V$ & $12^{\circ} 58^{\prime} 04^{\prime \prime}$ & $50^{\circ} 23^{\prime} 49^{\prime \prime}$ & 65 \\
\hline Brno - Kojál & $12 D$ & 10.0 & $V$ & $16^{\circ} 48^{\prime} 59^{\prime \prime}$ & $49^{\circ} 22^{\prime} 11^{\prime \prime}$ & 305 \\
\hline Zlín-Tlustá hora & $12 D$ & 10.0 & $V$ & $17^{\circ} 38^{\prime} 47^{\prime \prime}$ & $49^{\circ} 12^{\prime} 30^{\prime \prime}$ & 65 \\
\hline Klatovy-Doubrava & $12 C$ & 5.0 & $V$ & $13^{\circ} 12^{\prime} 15^{\prime \prime}$ & $49^{\circ} 25^{\prime} 56^{\prime \prime}$ & 35 \\
\hline Olomouc-Radikov & $12 D$ & 2.0 & $V$ & $17^{\circ} 22^{\prime} 05^{\prime \prime}$ & $49^{\circ} 38^{\prime} 32^{\prime \prime}$ & 67 \\
\hline Plzeñ - Sylván & $12 C$ & 1.0 & $V$ & $13^{\circ} 20^{\prime} 58^{\prime \prime}$ & $49^{\circ} 46^{\prime} 14^{\prime \prime}$ & 50 \\
\hline Nový Jičín - Veselý kopec & $12 D$ & 1.0 & $V$ & $17^{\circ} 48^{\prime} 19^{\prime \prime}$ & $49^{\circ} 38^{\prime} 40^{\prime \prime}$ & 69 \\
\hline Tasov - Za šibenicí & $12 D$ & 0.3 & $V$ & $16^{\circ} 06^{\prime} 52^{\prime \prime}$ & $49^{\circ} 16^{\prime} 51^{\prime \prime}$ & 21 \\
\hline Votice - Mezivrata & $12 \mathrm{C}$ & 10.0 & $\mathrm{~V}$ & $14^{\circ} 40^{\prime} 18^{\prime \prime}$ & $49^{\circ} 36^{\prime} 10^{\prime \prime}$ & 71 \\
\hline Jihlava - Javořice & $12 \mathrm{D}$ & 10.0 & $\mathrm{~V}$ & $15^{\circ} 20^{\prime} 22^{\prime \prime}$ & $49^{\circ} 13^{\prime} 17^{\prime \prime}$ & 104 \\
\hline Pardubice - Krásné & $12 \mathrm{C}$ & 10.0 & $\mathrm{~V}$ & $15^{\circ} 44^{\prime} 15^{\prime \prime}$ & $49^{\circ} 49^{\prime} 21^{\prime \prime}$ & 110 \\
\hline Jeseník - Praděd & $12 \mathrm{D}$ & 10.0 & $\mathrm{~V}$ & $17^{\circ} 13^{\prime} 52^{\prime \prime}$ & $50^{\circ} 04^{\prime} 59^{\prime \prime}$ & 93 \\
\hline Liberec - Proseč & $12 \mathrm{C}$ & 1.0 & $\mathrm{~V}$ & $15^{\circ} 07^{\prime} 46^{\prime \prime}$ & $50^{\circ} 44^{\prime} 35^{\prime \prime}$ & 20 \\
\hline Znojmo - Kuchařovice & $12 \mathrm{D}$ & 0.3 & $\mathrm{~V}$ & $16^{\circ} 05^{\prime} 09^{\prime \prime}$ & $48^{\circ} 52^{\prime} 53^{\prime \prime}$ & 20 \\
\hline Třinec - Javorový & $12 \mathrm{D}$ & 1.0 & $\mathrm{~V}$ & $18^{\circ} 37^{\prime} 38^{\prime \prime}$ & $49^{\circ} 37^{\prime} 40^{\prime \prime}$ & 40 \\
\hline Val. Meziříčí - Radhošt' & $12 \mathrm{C}$ & 1.0 & $\mathrm{~V}$ & $18^{\circ} 13^{\prime} 20^{\prime \prime}$ & $49^{\circ} 29^{\prime} 31^{\prime \prime}$ & 46 \\
\hline Sušice - Svatobor & $12 \mathrm{C}$ & 1.0 & $\mathrm{~V}$ & $13^{\circ} 29^{\prime} 23^{\prime \prime}$ & $49^{\circ} 14^{\prime} 06^{\prime \prime}$ & 40 \\
\hline
\end{tabular}

Tab. 5. The list and parameters of transmitters in the stage 5 (the new ones are marked in bold). 


\section{The Indoor DAB+ Reception}

According to CTO regulation No. 22/2011 [13], the intensity of the electromagnetic field required to receive the $\mathrm{DAB}+$ signal with subjectively unrecognizable impairments of sound quality is $58 \mathrm{~dB} \mu \mathrm{V} / \mathrm{m}$. The $\mathrm{DAB}+$ network of Czech Radio was built for this level. With this intensity of the electromagnetic field, $95 \%$ of the population of the Czech Republic is covered (in stage 5). For "Indoor and portable" scenarios however, coverage intensity of $66 \mathrm{~dB} \mu \mathrm{V} / \mathrm{m}$ is required [14]. This requirement is especially important in cities, which was also confirmed during the construction of this network. Additional measurements made by Czech Radio in cooperation with CRA in March 2019 in the cities of Prague and Pilsen confirmed that electromagnetic field intensity for large urban agglomerations must be increased. Indoor tests were conducted for two weeks inside 20 buildings in Prague and inside 10 buildings in Pilsen, primarily on the ground floors and first floors of business buildings and apartment buildings, where the reception conditions are the most difficult. Portable receivers Revo PiXiS and Pure One Elite with telescopic antennas were used for subjective evaluation. During the test, the quality of indoor reception was assessed for 15 minutes of listening in different parts of the apartment or office space. The reception was only evaluated in rooms that have a window.

The maps shown in Fig. 8 and Fig. 9 display the numerical modeling of the coverage of the City of Pilsen according to ITU for $66 \mathrm{~dB} \mu \mathrm{V} / \mathrm{m}$ and FEC 2A. The map in Fig. 8 shows this coverage without an additional city transmitter, relying only on the main regional transmitter Plzeň - Radeč (10 kW ERP), located $25 \mathrm{~km}$ from the city. The map in Fig. 9 shows the same coverage but with the additional city transmitter Plzeň - Sylván (1 kW ERP), located directly in the city. As seen, the improvement of the indoor coverage is significant.

The most problematic areas were already solved within the relevant stages of the network construction (Pilsen, Liberec, Znojmo and Trrinec). However, there are other cities in the Czech Republic, where the use of additional low-power transmitter located inside the city would significantly increase the quality of indoor reception. This will be the subject of further research and further development of this network.

\section{The Audio Processing}

The key point of $\mathrm{DAB}+$ network is the sound and its transmission from the broadcasting studio to the listeners with maximum subjective quality (i.e. with subjectively unrecognizable impairments of sound quality). When considering audio quality in the context of $\mathrm{DAB}+$, attention is usually focused on the use of lossy compression, especially on the dedicated bitrates. In fact, it does not have to be a major problem when using the modern version of $\mathrm{DAB}+$ [3], [7]. This system is designed so that subjectively per-

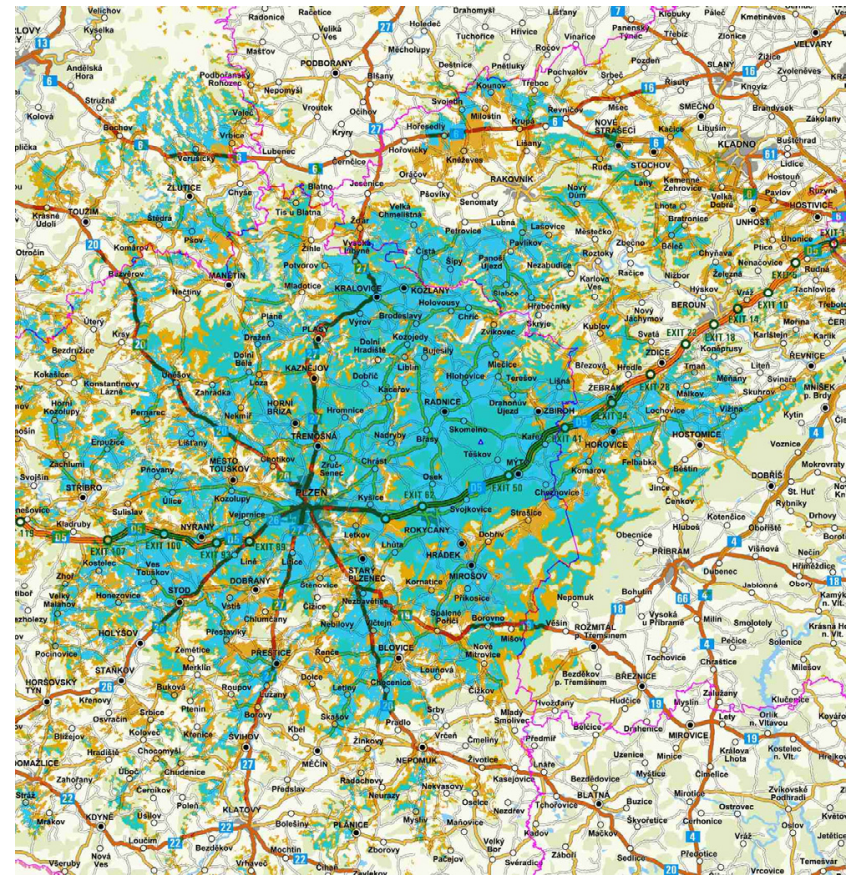

Fig. 8. The numerical modeling of the coverage of the City of Pilsen according to ITU for $66 \mathrm{~dB} \mu \mathrm{V} / \mathrm{m}$ and FEC $2 \mathrm{~A}$ without an additional city transmitter.

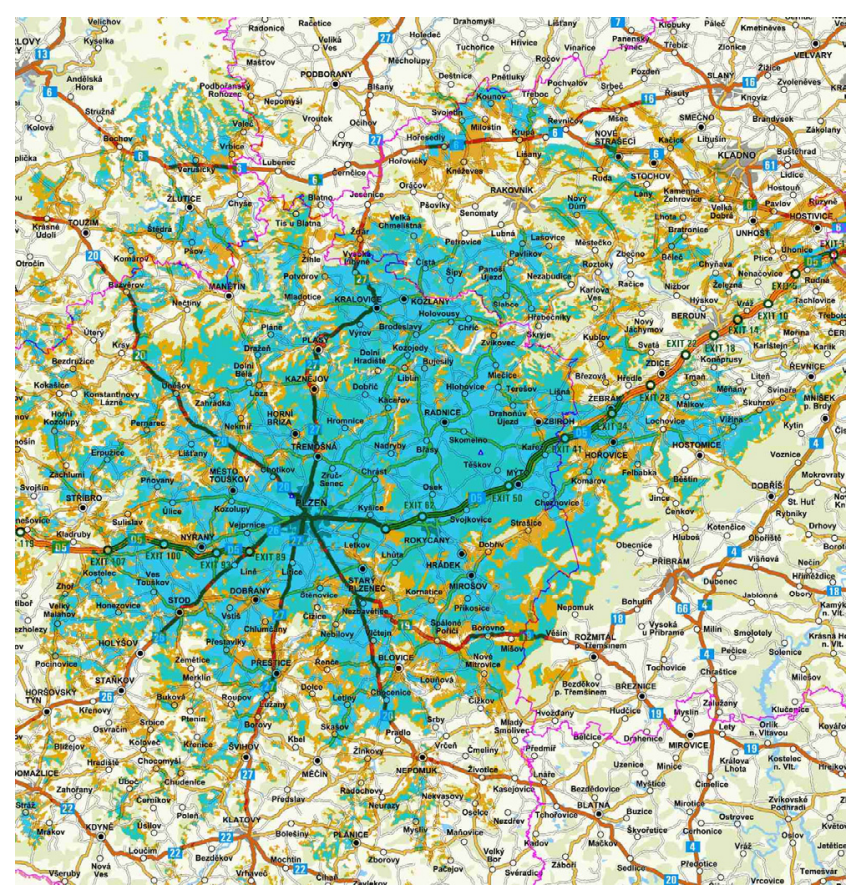

Fig. 9. The numerical modeling of the coverage of the City of Pilsen according to ITU for $66 \mathrm{~dB} \mu \mathrm{V} / \mathrm{m}$ and FEC $2 \mathrm{~A}$ with the additional city transmitter Plzeň - Sylván.

ceived high quality audio transmission can be achieved even at relatively low bitrates, about $48 \mathrm{kbps}$, if a suitable codec is deployed. The crucial factor, however, is the correct preparation of the audio signal before the $\mathrm{DAB}+$ coding itself. The primary sound quality and the concatenation of different non-entropic lossy compression audio coding (MPEG2, MP3, AAC, etc.), used in the individual technological stages (primary source, radio music library, distri- 
bution, $\mathrm{DAB}+$ transmitter) has the dominant influence on the result [3]. It is therefore desirable to minimize the number of such concatenated transcoding between non-entropic audio codecs [15] and to keep the signal path lossless as much as possible. In the case of the $\mathrm{DAB}+$ network of Czech Radio, the entire signal path from the broadcasting studio to the audio encoder is completely lossless in the AES3 (also known as AES / EBU) protocol [16]. The $\mathrm{DAB}+$ audio encoders are separated from the headend itself and are located directly in the broadcasting building (see Fig. 10). Czech Radio uses DSP based hardware audio encoders AVT MAGIC AE1 DAB+ Go [17]. They encode the audio into HE-AAC algorithm and then transport it over IP to an ensemble multiplexer. This eliminates any necessary transcoding between lossy audio codecs.

A separate important issue is the broadcast audio processor which conditions the final output of the audio signal. It is always used at the end of the broadcasting chain and its use is essential. Its main purpose, however, differs in analog (FM) and digital (DAB + ) platforms. While in $\mathrm{DAB}+$ its main purpose is to process audio in an artistic way, in the FM broadcasting it is additionally responsible for compliance with telecommunications standards [18]. If the same audio program is broadcasted simultaneously on an analog (FM) and digital (DAB+) platform, as is the case with Czech Radio, it is desirable to provide separate audio processing for both platforms (see Fig. 11) [19], [20]. The audio codec HE-AAC used in $\mathrm{DAB}+$ is very sensitive to appropriate signal pre-processing [21], [22]. The broadcast audio processor set for analog FM must clip the signal peaks to keep it within the telecommunication standard range [18]. Applying such a signal to the HE-AAC codec makes it inefficient, resulting in impairments of the processed sound.

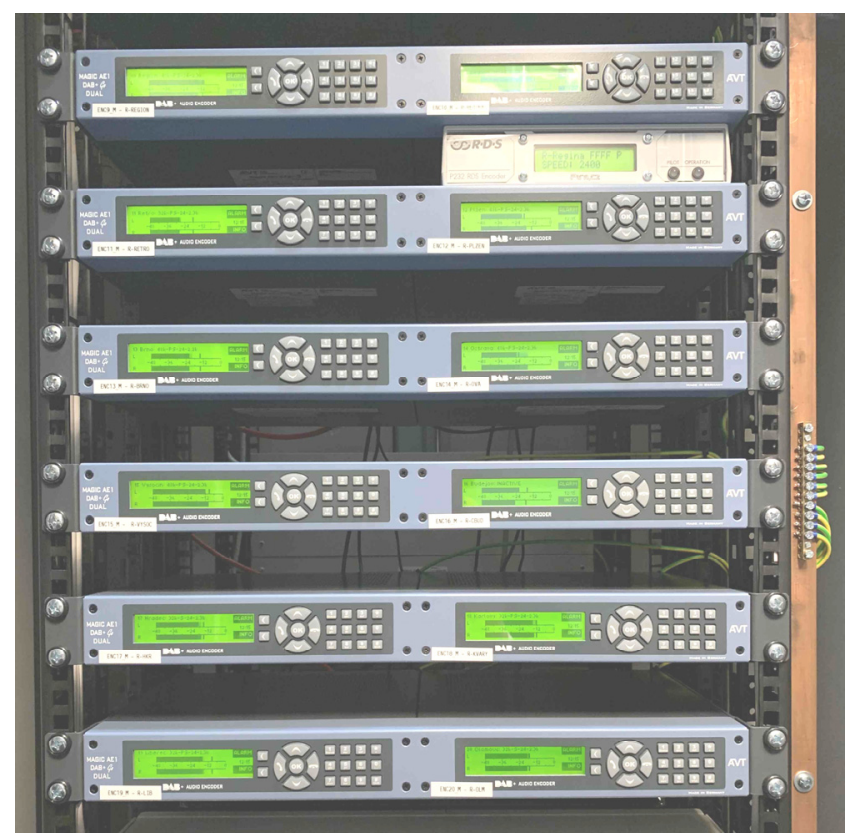

Fig. 10. The AAC audio encoders of the Czech Radio DAB+ network.

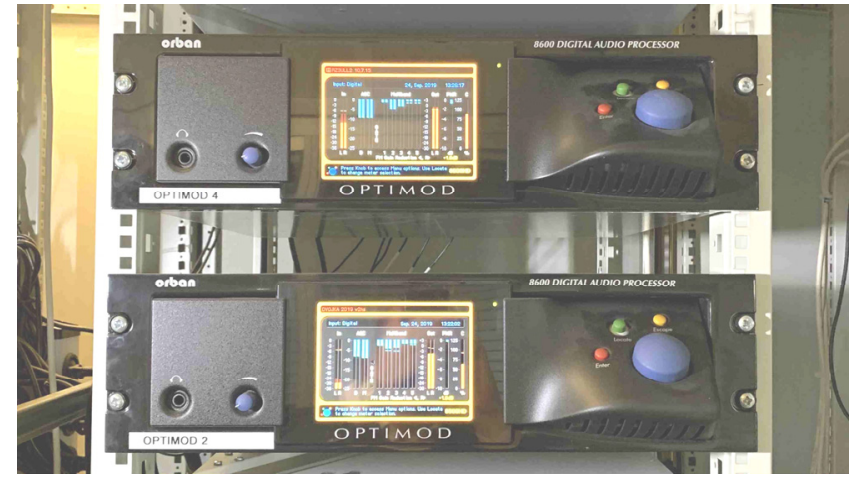

Fig. 11. The broadcast audio processors providing a separate audio processing for analog (FM) and digital (DAB+) platforms, used in the Czech Radio DAB+ network.

The psycho-acoustic non-entropic lossy compression used in $\mathrm{DAB}+$ is very sensitive to clipping products. If clippings are present in the input signal, the compression algorithm tries to encode them. It can take some amount of available bitrate. New spectral components generated by clipping can seriously degrade the quality of encoding. Audible signals are then coded with lower effective bitrate, with lower sound quality. The broadcast audio processor should not contain any output clipper, or it should only contain a special type of logarithmic clipper. Such clipper produces low amount of clipping by-products in the output signal. The right solution is based on controlling peaks of the audio signal by dynamically allocated scale factor for lossy psycho-acoustic encoder. This technology, unlike simple clipping, analyses waveform of audio by lookingforward technique. For every half wave of a signal the specific scale factor is computed and then all audio samples of this half wave are multiplied by this factor. Such type of processing completely avoids clipping [23]. Czech Radio uses this new type of final signal processing on DAB stations Radio DAB Prague and Radio Wave.

\section{Conclusion}

This paper describes the experience and the results from the implementation of the first nationwide $\mathrm{DAB}+$ network in conditions of the Czech Republic. The progress in particular stages is displayed on the maps of coverage. They represent a numerical model of the network coverage according to ITU for $58 \mathrm{~dB} \mu \mathrm{V} / \mathrm{m}$ and FEC $2 \mathrm{~A}$. The practice in real conditions confirmed that $\mathrm{DAB}+$ network build with protection level FEC 2A and with the backbone based on high-power transmitters (10-20 kW ERP) at high latitudes leads to quick and effective penetration of the signal coverage. The downside of higher protection level is the higher consumption of multiplex bitrate capacity. It is $25 \%$ more in FEC 2A in comparison to the commonly used FEC 3A. This disadvantage could be compensated using effective audio coding HE-AAC v1 or v2, which reduces the necessary multiplex capacity dramatically. The practice also verified the results of blind listening tests carried out by Czech Radio [3]. The audio coding itself, if properly 
used, does not have a significant impact on the subjective perception of sound quality by the audience. What is crucial is the primary sound quality and correct pre-processing of the audio signal. It is desirable to minimize the concatenation of different non-entropic lossy compression audio coding and transcoding between them and to keep the signal path lossless as much as possible. The final processing done by the broadcast audio processor should always be separated from analog broadcasting and should use the appropriate peak control algorithm because the efficiency of HE-AAC coding is negatively influenced by peak clipping as used in analog processing. $\mathrm{DAB}+$ network of Czech Radio provides a reliable $\mathrm{DAB}+$ signal reception with high subjective sound quality. The indoor DAB+ reception in big agglomerations, however, requires an increase of the homogeneity of the electromagnetic field from $58 \mathrm{~dB} \mu \mathrm{V} / \mathrm{m}$ to $66 \mathrm{~dB} \mu \mathrm{V} / \mathrm{m}$ for which additional local transmitters are needed inside large urban areas.

\section{References}

[1] HOEG, W., LAUTERBACH, T. (Eds.) Digital Audio Broadcasting: Principles and Applications of $D A B, D A B+$ and $D M B$. 3rd ed. John Wiley \& Sons, 2009. ISBN: 978-0-470-51037-7

[2] ETSI ETSI European Standard EN 300401 V2.1.1 Radio Broadcasting Systems; Digital Audio Broadcasting (DAB) to Mobile, Portable and Fixed Receivers, 01/2017.

[3] ZYKA, K. The digital audio broadcasting journey from the lab to listeners - the Czech Republic case study. Radioengineering, 2019, vol. 28, no. 2, p. 483-490. DOI: 10.13164/re.2019.0483

[4] ETSI ETSI Technical Specification TS 102 563, Digital Audio Broadcasting (DAB); Transport of Advanced Audio Coding (AAC) Audio, Sophia Antipolis Cedex, France, 2010.

[5] HERRE, J., DIETZ, M. MPEG-4 high-efficiency AAC coding [Standards in a nutshell]. IEEE Signal Processing Magazine, 2008, vol. 25, no. 3, p. 137-142. DOI: 10.1109/MSP.2008.918684

[6] ETSI ETSI Technical Specification TS 103466 V1.1.1. Digital Audio Broadcasting (DAB); DAB Audio Coding (MPEG Layer II), $10 / 2016$.

[7] ITU RADIOCOMMUNICATION SECTOR, GENEVA SWITZERLAND. Method for the Subjective Assessment of Intermediate Quality Levels of Coding Systems. Recommendation ITU-R BS.1534. 2001-2015. Approved in 2015-10.

[8] ITU RADIOCOMMUNICATION SECTOR, GENEVA SWITZERLAND. Method for Point-to-Area Predictions for Terrestrial Services in the Frequency Range $30 \mathrm{MHz}$ to $3000 \mathrm{MHz}$. Recommendation ITU-R P.1546-2. Approved in 2013-09.

[9] WORLD DAB - The official Database of the Latest Information on Regulatory Frameworks, DAB+ Network Coverage, Services on Air. [Online] Available at: https://www.worlddab.org/countries

[10] NATIONAL REGULATORY AUTHORITY (CTO) Press Release about the Experimental Broadcasting "DAB Prague". Czech Republic, 2015. [Online] Available at: https://www.ctu.cz/tiskova-zprava-ctu-podporil-experimentalnivysilani-t-dab

[11] ITU RADIOCOMMUNICATION SECTOR, GENEVA SWITZERLAND. A Path-specific Propagation Prediction Method for Point-to-Area Terrestrial Services in the VHF and UHF Bands. Recommendation ITU-R P.1812-3. Approved in 2013-09.
[12] CRC DATA - RADIOLAB version 4.3.1. The Software Modeling System. [Online] Available at: https://www.crcdata.cz/index.php/radiokomunikace/radiolab-4

[13] NATIONAL REGULATORY AUTHORITY (CTO) Regulation No. 22/2011 on the Method of Setting the Coverage of Terrestrial Radio Broadcasting in Selected Bands, Czech Republic, 2011.

[14] GE06, Final Acts of the Regional Radiocommunication Conference for Planning of the Digital Terrestrial Broadcasting Service in Parts of Regions 1 and 3 , in the Frequency Bands 174-230 MHz and 470-862 MHz (RRC-06). Geneva, 2006.

[15] STRANAK, P. New methods of stereo encoding for FM radio broadcasting based on digital technology. Radioengineering, 2007, vol. 16, no. 4, p. 12-17. ISSN: 1210-2512

[16] EBU TECH 3250, GENEVA SWITZERLAND. Specification of the Digital Audio Interface (AES/EBU). European Broadcasting Union, 3rd ed., 2004.

[17] AVT MAGIC AE1 DAB+ Go. The High Quality and Professional DSP-based Hardware Audio Encoder. [Online] Available at: https://www.avt-nbg.de/en/products/magic-ae1-dab-go

[18] ITU RADIOCOMMUNICATION SECTOR, GENEVA SWITZERLAND. Planning Standards for Terrestrial FM Sound Broadcasting at VHF. Recommendation ITU-R BS.412-9. Approved in 1998-12.

[19] BONELLO, O. J. Multiband audio processing and its influence on the coverage area of the FM stereo transmission. Journal of Audio Engineering Society, 2007, vol. 55, no. 3, p. 145-156.

[20] STRANAK, P. Interfering DC component, suppression and influence to digital signal processing. Radioengineering, 2008, vol. 17 , no. 3, p. 121-123. ISSN: 1210-2512

[21] GILSKI, P. DAB vs DAB + radio broadcasting: A subjective comparative study. Archives of Acoustics, 2017, vol. 42, no. 4, p. 715-723. DOI: 10.1515/aoa-2017-0074

[22] ITU RADIOCOMMUNICATION SECTOR, GENEVA SWITZERLAND. Audio Coding for Digital Broadcasting. BS Series Broadcasting Service (Sound). Recommendation ITU-R BS.1196-7. Approved in 2019-01.

[23] STRANAK, P., DOBES, J. Controlling peaks of the audio signal by dynamically allocated scale factor for lossy psychoacoustic encoder. In 53rd IEEE International Midwest Symposium on Circuits and Systems. Seattle (USA), 2010, p. 388-391. DOI: 10.1109/MWSCAS.2010.5548874

\section{About the Author ...}

Karel ZÝKA was born in Prague, the Czech Republic, in 1967. He received his M.Sc. from the Faculty of Electrical Engineering at the Czech Technical University in Prague in 1992. He is employed at Czech Radio, a national public service broadcaster, where he is the Technical Director and the head of the digital switchover team, which is implementing the DAB+ in the Czech Republic. He is a member of WorldDAB and EDRA Steering Boards and works for the EBU. In the past, he was engaged at Radio Alfa, implementing the first satellite distribution system in the Czech Republic, and at TV Prima, where he participated in the DVB-T transformation. Currently, he is an external postgraduate Ph.D. student at the Department of Sound Design at the Academy of Performing Arts in Prague (HAMU). 